\title{
非機能性下垂体腺腫の免疫組織化学的・電顕的検討
}

ゴナドトロピン産生腺腫との関連性について

宮崎 宏道・戸谷 重雄・大谷 光弘・和田 知益*.亀谷 徽*

\section{Immunohistochemical and Electron Microscopic Study of Nonfunctioning Pituitary Adenomas}

With Special Reference to Gonadotroph Adenomas

\author{
Hiromichi Miyazaki, Shigeo Toya, Mitsuhiro Otani, Chieki Wada* \\ and Toru KAMEYA* \\ Department of Neurosurgery, Keio University, Tokyo; ${ }^{*}$ Department of Pathology, Kitasato University, \\ Sagamihara, Kanagawa
}

\begin{abstract}
Immunohistochemical techniques and electron microscopy were employed in a study of nine surgical patients with nonfunctioning pituitary adenomas and no clinical or biochemical evidence of increased hormone secretion. Six of the patients were found to have gonadotroph adenomas, which exhibited extensive immunostaining for gonadotropins, and the remaining three appeared to have null cell adenomas, which showed no reactivity for any pituitary hormone. Clinically, it was difficult to distinguish these two groups of patients. Gonadotroph adenomas are likely to have low secretory activity, resulting in normal or slightly high serum gonadotropin levels. In addition, some common histopathological features were observed in the two groups: a predominantly papillary, sinusoidal pattern; rather poorly developed cell organelles, with the exception of an abundance of mitochondria; and small, round secretory granules dispersed throughout the cytoplasm. It is possible that null cell adenoma produces so little gonadotropin that it is not detectable by immunohistochemistry. In this study, two thirds of the nonfunctioning adenomas were, in fact, gonadotroph adenomas. The authors speculate that there is a common cytogenesis of gonadotroph adenomas and some, if not all, null cell adenomas.
\end{abstract}

Key words: pituitary adenoma, gonadotropin, immunohistochemistry, electron microscopy

\section{Iはじめに}

下垂体腺腫は，血中前葉ホルモンの異常高值抢よび特徵 的な内分泌徵候を伴った機能性腺腫と，それらを欠いた非 機能性腺腫とに臨床上大別される。․方，近年報告の増觉 ているゴナドトロピン産生腺腫 (gonadotroph adenoma ${ }^{61}$ ) は
通常特徵的な臨床徵候を持たないため，しばしば非譏能性 腺腫とされている可能性がある.今回我々は，最近経験し 大 9 例の非機能性腺腫を免疫組織化学的扰よび電影的に検 討した結果，6例が形態的にゴナドトロピン産生腺腫と考 光ら机た。な，ホルモン免疫活性を示さない残りの3 例，いわゆる null cell adenoma ${ }^{9}$ にも形態的にそれと類似

\footnotetext{
慶應義熟大学脳神経外科 *北里大学病理

Address reprint requests to: H. Miyazaki, M.D., Division of Neurosurgery, Hiratsuka City Hospital, 1-19-1 Minamihara, Hiratsuka, Kanagawa 254.

受稿 1987 年 5 月 7 日 受理 1987 年 8 月20日
} 
した所見を認めた。非機能性腺腫とゴナトトロピソ産生腺 腫の関連性に関し，考察を加兄た。

\section{II 対象と方法}

慶應義塾大学脳神経外科にて1985年 5 月上り翌年 8 月本 でに手術された非機能性下垂体腺腫 9 例を対象とした。同 時期に手術された機能性腺腫14例〔ブロラクチン(以下 PRL) 産生 7, 成長木ルモン(以下 GH) 産生 6, 向副腎皮質 ホルモン(以下 $\mathrm{ACTH}$ ) 産生 1】にも同様の検索を行った。

手術材料在光顕用以はブフン固定，パラフィン包埋後， 切片を作製し，HE染色を施した。電影用には組織を $2.5 \%$ グルタルアルデヒド拈よび $2 \%$ オミウム酸にて固 定, エポン包埋後，切片を作製し，電子二重染色ののち， JEM100SX 透過型電子䫒徽鏡にて観察した，免疫染色は 光顕用切片に対し， avidin biotin complex 法》にとて行い， 抗体は GH, PRL, ACTH，そして甲状腺刺激ホルモン(以 下 TSH)，黄体化ホルモン(以下 LH)，卵胞刺激ホルモン

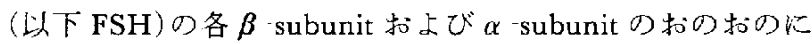
対するものを使用した（前三者は Immuno Nuclear 社より， 後四者は National Institute of Arthritis, Diabetes and Digestive and Kidney Disease : 以下 NIADDKより入手). 反応の特異性は，特異抗体の代りに正常血清あるいは抗原 (NIADDK)にて吸收した抗体を使用し，反応の陰性化す ることにより確認した，後四者の特異抗体間の交差反心仙は 交差吸收試験にて除外した。本た，内分泌細胞の分泌顆粒 のマーカーとされる chromogranin ${ }^{15}$ ) の抗体 (Immuno Nuclear 社)に対する反応性を同時に検索した。

\section{III 結 果}

非機能性腺腫々臨床診断された 9 例のうち，6例が免疫 染色の結果, gonadotroph adenoma (以下 GtA) と考光られ た。以下，その臨床的，病理組織学的な特徵を述べ，また 残りの 3 例の null cell adenoma（以下 NcA）上比較する.

\section{1. 臨床的所見 (Table 1)}

GtAの6 例は中高年 (平均57.2才) の男性 4 例，女性 2 例 であり，主訴は無月経，乳计分泌の〈症例 4〉を除き，視力 視野障害で，その 5 例は入院時に両耳側半盲を示した。男 性では libido の低下を訴えることが多く，また女性では無 月経を認めたが，いずれも長期にわたる性腺機能不全を有 するものはなく，身体所見でも正常な性徴候を示した。

CT scan 上.4鞍上進展を示す軽度高吸収の macroadenoma で，造影剂にて増強された，2例ではcyst と思われる低吸 収域を含んでいた，内分泌学的検查ではGtAの血中ゴナ トトロピン值は活添正常範囲内にあり，〈症例 1，6〉では FSHがやや高值を示したが，高夦に上るもの子考光，正 常範囲内と判断された。 LH releasing hormone（以下 LHRH) 負荷試験 (早朝空腹時 LHRH $100 \mu \mathrm{g}$ 静注) では, 全例 FSH，LHの上昇反応を示した。他のホルモンでは 〈症例 4〉RPRLの軽度上昇があり，〈症例 $1,3,5,6$ では 下垂体予備能力の一部低下を認め心。手術で柱〈症例 3，5〉 で CT scan の低吸收域に一致して茶褐色液を含む cyst 認めたが，他の 4 例は充実性の通常の下垂体腺腫の所見で 市った。

NcAの 3 例子概して類似した所見を示し，臨床的側面

Table 1 Clinical features of nine patients with nonfunctioning adenomas

\begin{tabular}{|c|c|c|c|c|c|c|c|c|c|}
\hline \multirow{2}{*}{ Case No. } & \multirow{2}{*}{ Age, Sex } & \multirow{2}{*}{ Chief complaint } & \multirow{2}{*}{$\begin{array}{l}\text { Loss of } \\
\text { libido }\end{array}$} & \multirow{2}{*}{$\begin{array}{l}\text { Suprasellar } \\
\text { extension }\end{array}$} & \multirow{2}{*}{ Cyst } & \multicolumn{2}{|c|}{$\mathrm{LH}(\mathrm{mIU} / \mathrm{m} l)$} & \multicolumn{2}{|c|}{$\mathrm{FSH}(\mathrm{mIU} / \mathrm{m} l)$} \\
\hline & & & & & & Base & Peak & Base & Peak \\
\hline \multicolumn{10}{|c|}{ Gonadotroph adenomas: } \\
\hline 1 & $71, \mathrm{M}$ & visual disturbance & + & + & - & 23 & 40 & 48 & 61 \\
\hline 2 & $58, \mathrm{M}$ & visual disturbance & + & + & - & 24 & 34 & 19 & 25 \\
\hline 3 & $51, \mathrm{M}$ & visual disturbance & - & + & + & 11 & 25 & 10 & 16 \\
\hline 4 & $46, \mathrm{~F}$ & amenorrhea/galactorrhea & & + & - & 4 & 44 & 4 & 18 \\
\hline 5 & $50, \mathbf{M}$ & visual disturbance & + & + & + & 11 & 24 & 10 & 19 \\
\hline 6 & $67, \mathrm{~F}$ & visual disturbance & & + & - & 15 & 29 & 32 & 85 \\
\hline \multicolumn{10}{|c|}{ Null cell adenomas: } \\
\hline 7 & $48, \mathrm{M}$ & visual disturbance & + & + & - & \multicolumn{4}{|c|}{ not examined } \\
\hline 8 & $50, \mathrm{~F}$ & visual disturbance & & + & - & 5 & 11 & 5 & 11 \\
\hline 9 & $45, \mathrm{~F}$ & visual disturbance & & + & - & 10 & 29 & 8 & 19 \\
\hline
\end{tabular}

The normal ranges of luteinizing hormone ( $\mathrm{LH}$ ) are 4 to 23 in males less than 40 years old and 3 to 20 in premenopausal females. For follicle stimulating hormone (FSH) the normal ranges in the same age groups are 2 to 18 and 3 to 13 , respectively. In males over age 40 and in postmenopausal females, LH and FSH are higher. Peak indicates peak for LH releasing hormone test. 
かららは両者の区別は困難であったと思われる。

2. 病理組織学的所見 (Table 2)

GtA にはHE 染色にて好酸性を呈するものがあり。こ れは後述する oncocytic changeを反映したるの女思わ机 る9101. Pleomorphism 扰よび mitosis 㥜めら机ない. 血 管の増生をしはしば認め, sinusoidal 放いし papllary 構 築を主々する症例が多く，NcAでも2 例に同样な傾向を 認めた。同時期に手術された14例の機能性腺睡结い寸饥も diffuse 細胞構築が主であった。

免疫染色てはGtA 上 N A が明らかに区別された。すな わち，〈症例 1〜6〉で济コナトトロどン陽性の細胞を組織 中に広汎に認めた（Fig. 1A)が，〈症例 7〜9〉はすべての木 ルモンに詨し反仙院性てあった(Fig. 2A)。一才，電顕所 見ではGtAに共通した特徴がいくつか挙げら机る(Fig. 1B)。核は概して類円形て，核小体は顕著て状ない。細胞 質は豊富で，丸味を带びた多角形のものが多く，血管周柬

Table 2 Pathological features of nine nonfunctioning adenomas

\begin{tabular}{|c|c|c|c|c|c|c|c|c|}
\hline Case No & HE stain & $\mathrm{LH} \beta$ & $\mathrm{FSH} \beta$ & $\alpha$-subunit & Chromogranın & $\begin{array}{l}\text { Oncocytic } \\
\text { change }\end{array}$ & $\begin{array}{c}\text { Secretory } \\
\text { granules }(\mathrm{nm})\end{array}$ & $\begin{array}{l}\text { Development of RER } \\
\text { and Golg1 apparatus }\end{array}$ \\
\hline \multicolumn{9}{|c|}{ Gonadotroph adenomas } \\
\hline 1 & $\mathrm{~A} / \mathrm{D}+\mathrm{P}$ & + & + & $H$ & W & severe & $100-150$ & poor \\
\hline 2 & $\mathrm{C}+\mathrm{A} / \mathrm{S}+\mathrm{D}$ & H & H & H & H & moderate & $80-130$ & moderate \\
\hline 3 & $\mathrm{C}+\mathrm{A} / \mathrm{S}$ & H & H & H & H & moderate & $100-200$ & moderate \\
\hline 4 & $\mathrm{C} / \mathrm{P}$ & H & H & H & H & moderate & $100-200$ & moderate \\
\hline 5 & $\mathrm{C}+\mathrm{A} / \mathrm{P}+\mathrm{D}$ & + & $H$ & + & H & severe & $80-200$ & poor \\
\hline 6 & $\mathrm{C} / \mathrm{D}$ & - & H & W & H & & & \\
\hline \multicolumn{9}{|c|}{ Null cell adenomas } \\
\hline 7 & $\mathrm{~A} / \mathrm{D}$ & - & - & - & - & severe & $80-150$ & poor \\
\hline 8 & $\mathrm{C} / \mathrm{S}$ & - & - & - & H & moderate & $60-130$ & poor \\
\hline 9 & $\mathrm{C} / \mathrm{D}+\mathrm{P}$ & - & - & - & - & mild & $60-120$ & moderate \\
\hline
\end{tabular}

In Case 6, the electron microscopy sample was inadequatc. A indicates acidophilic, C, chromophobe, D, diffuse, P, papillary, S, sinusoidal, RER, rough endoplasmic retıculum - , , + , and $\#$ indicate negative, weak, moderate, and strong immunoreactivity, respectively

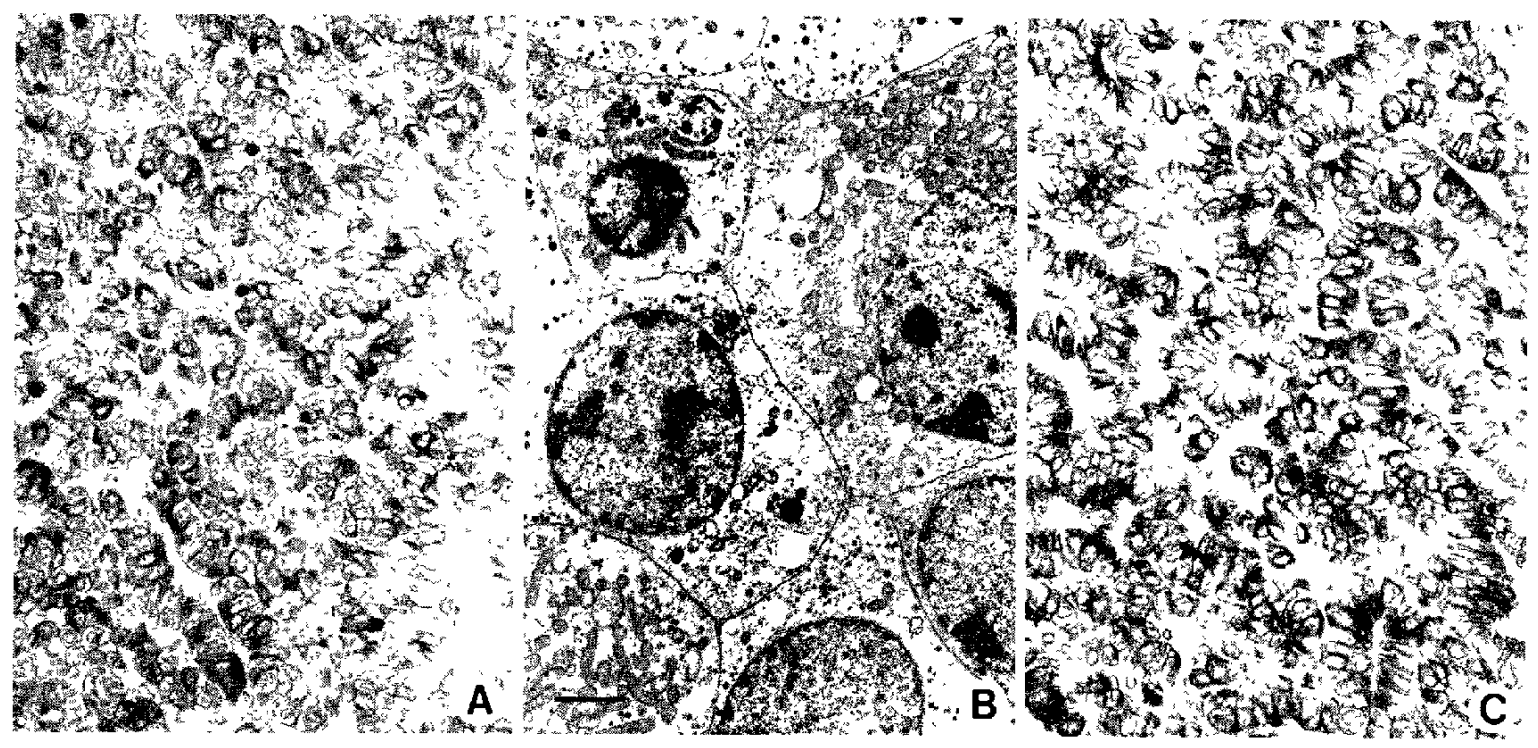

Fig. 1 Case 4 Gonadotroph adenoma. A Many cells are immunoreactive for gonadotropın [ $\beta$-subunit of follicle stımulatıng hormone $(\mathrm{FSH} \beta)$ ] Immunoperoxıdase stain, $\times 200 \quad$ B: Elcctron micrograph reveals oncocytic changes in some cells. Bar $=2 \mu \mathrm{m}$. C Most cells show immunoreactivity for chromogranın Immunoperoxidase stain, $\times 200$ 

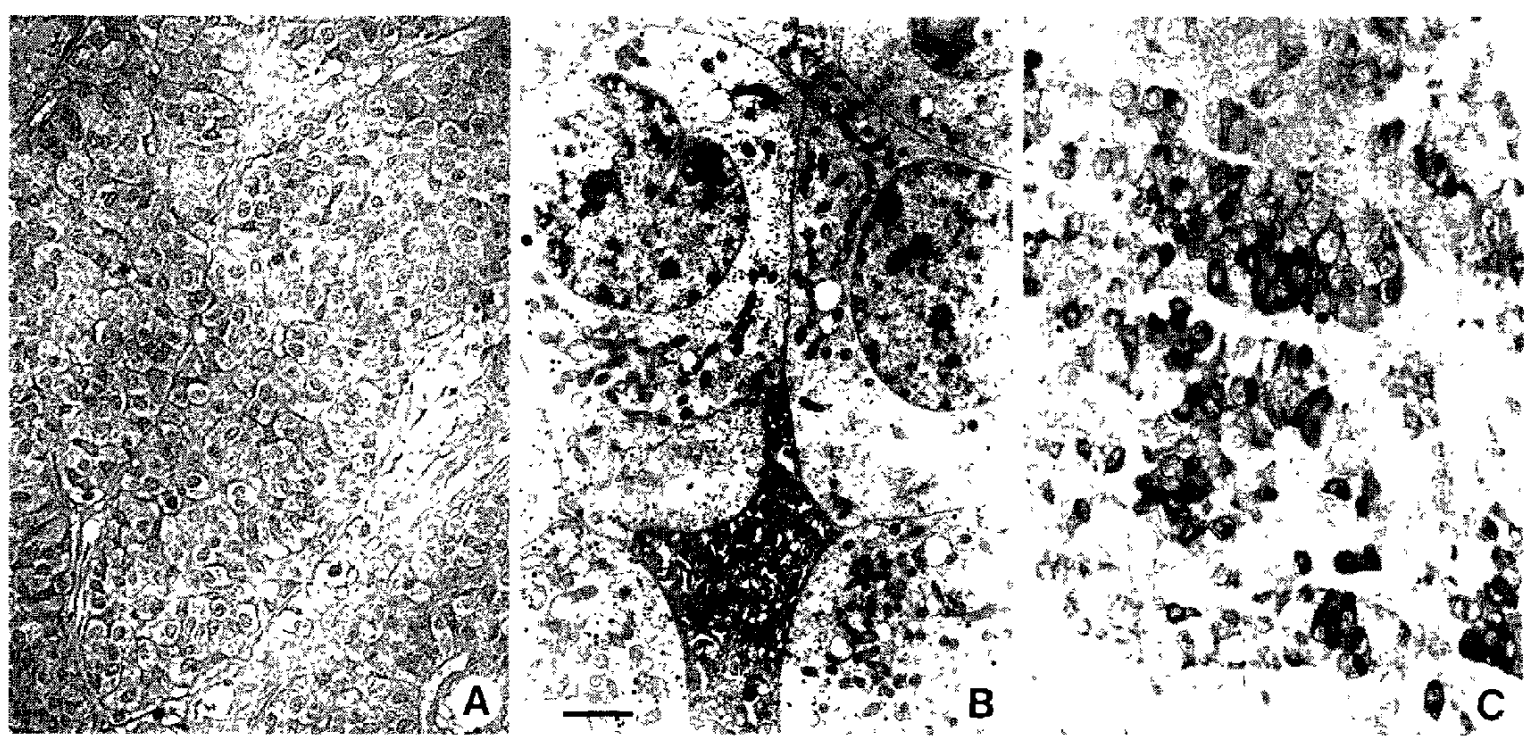

Fig 2 Case 8 Null cell adenoma. A No hormone is detected Immunoperoxidase stain (FSH $\beta$ ), $\times 200$. B Electron micrograph reveals oncocytic change $\mathrm{Bar}=2 \mu \mathrm{m}$

C. Some cells show immunoreactivity for chromogranin. Immunoperoxıdase stain, $\times 200$

では長す形ないし紡錘形を示するのも認める。細胞内器官 では粗面小胞体, Golgi 装置は多くの細胞に認められるも のの, GH 産生腺腫やPRL 産生腺腫に比べると, 明らか に発達は不良てある。分泌顆粒は忏形て80〜200 nm と小 型で，細胞質内に diffuse 汇分布しており，数は症例によ

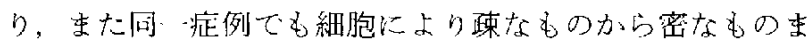
であり，一定していない、ミトコントリアの增生，与なわ ち oncocytic change t示吉細胞の多いのが特徵で，〈拝例 1, 5〉は形態的には oncacytoma ${ }^{10 !}$ 上考克られた。数倜の lysosomeを認める細胞が多い.NcAの電顕所見でもGtA に類似した特街を認めた(Fig. 2B)。まず, oncocytic change を示す細胞が多く，〈店例 〉〉 oncocytoma と又な された。他の機能性腺腫ては著明な oncocytic change を示 するのはなかった。尤た，粗面小胞体，Golg1装置の発達 は概してト良でり，分泌顆粒は円形，小型て，細胞内に diffuse江存在し，その数は GtA と比べて必ずしも少なく なかった。以上，GtA 上 NcA とは免疫染色にて区別でき るが，形態的には決定的な違いを指摘することはだきなか った。

Chromogranin に対する免疫反応では，GtAの6例は全 例陽性を示し(Fig. 1C)，NcAても1例が陽性を示した (Fig. 2C)。他の機能性腺睡ては、コナトトロピン陽性細 胞を含んボ 3 例の GH 産生腺腫以外はすべて陰性であっ た。

Neurol Med Char (Tokyo) 28, May 1988

\section{$\mathrm{N}$ 考察}

機能性下垂体腺腫のなかてTSH 産生腺腫, コナトトロ と゚ン産生腺腫はまれなものとされる8!.ゴナドトロピン産 生腺腫に関しては，他のホルモン産牛腺腫のよらに特徽的 な内分必供候が知的ていないため，“機能性”の意味す るところはゴナトトャピンの異常分泌，すな⿰力口血中值の 上昇の久となるら。し力し，過去の報告例の5ち先疫組織 化学的に確認され，加つ内分泌テ一夕の揃った45 例2-6,13,14,20,21：を調べてみると，血中值の上昇在伴わ寸，免 投組織化学的にの証明されたものが15例 4,6,14,20,21) ある。 これらは今回の我々の6 例を含め，定義上は“非機能性” と分類されて然る心゙きでるが，ホルモン含有が証明され るかきり，細胞にそのホルモン産牛能がある可能性はきる めて高いと思われ，“機能性”ではなくとも “産牛”'腺腫

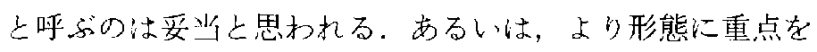
置いて、コナトトロロピン細胞腺腫 (gonadotroph adenoma $a^{6 〉}$ )

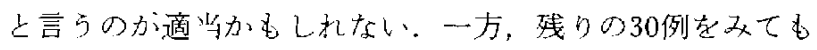
コナトトロピン值の上杽仗軽度のものが多く, 正常上限の 2〜5倍以内のものが注とえどで，高いものでも約10倍で ある、ところが、コナトトロピンは正常者です男女とも中 年以降，加齢とともに上昇を小場合があると当院に拟 る正常対照者：男性15名(43〜84才)て最高的4倍まで，女 性28名(49〜93才)で最高約16倍まで丁ため, 多少の上昇は

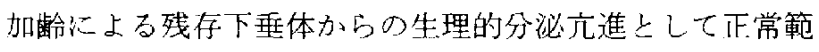
进内とさ扎ることも多いかと思私るる。奏際に血中值の上

Neurol Med Chur ( $T$ okyo) 28, May 1988 
昇が腫瘍性なのか否かの区別には，前者ではFSH が優位 を示すこと19)，LHRH 試験で peak FSH/LHが>1交す

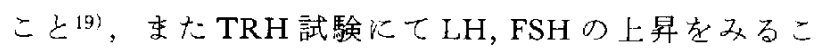
と畐が指標になるといらが，必ずしも絶対的ではない，し たがって，GtAは血中值の上昇を半わないるのはもちろ 几, 機能性 (血中値の上昇老伴うもの)であっても，免疫組 織化学的検索がなされないがり，いわゆる非機能性腺腫 とされる可能性が高い4,13).今までに非機能性腺腫と分類 されていたもののうち，かなりの部分を $\mathrm{GtA}$ が占めるの ではないか子推測される。

上述のごとく、GtAのゴナドトロピン值は軽度上昇な いし正常範囲内であるのが特徴と思われる。血中值の高い GtA の組織培養で, 他の機能性腺腫に比べ, 培養液中一 のホルモン分泌量の低いことが指摘されて沶り ${ }^{13,17)}$ ，この 特徵は腫痬自体の性質によるものと考兄られる. 形態上の 粗面小胞体や Golgi 装置の発垟不良, 支るい: oncocytic change が分泌量の低さに関与している可能性がある ${ }^{12,13)}$. 一方では細胞内に顆粒を多少とも認めること，免疫染色で かなりの細胞がホルモン陽性であることを考光ると，なん

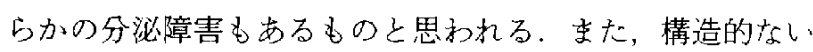
し免疫活性的に正常と異なるホルモンが分泌されている可 能性も举げられる21\}.

臨床的名称である非機能性腺腫火対伦する形態的な名称 として, 従来ょり chromophobe adenoma, undifferentiated cell adenomaなどが使わ机てきだが，最近では Kovacs ら9ににより提唱された null cell adenoma といら名前が広む ってきている。これは臨床的, 内分泌学的にホルモン分泌 充進が示崚されず, かつ免疫組織化学的にホルモン含有が 証明されないもの上定義されている.我々の9例の非機能 性腺腫のうち，6例は免疫染色にて広汎に強くゴナドト口 ピン陽性反応を認め, 病理組織学的には GtA と考光られ た. 残りの 3 例が NcAK相当する. しかし，今回の泟例 に限って言之ば，この両者は光顕上あるいは電顕上，形態 的に区別がつきがたく，むしろ共通した特改を有する傾向

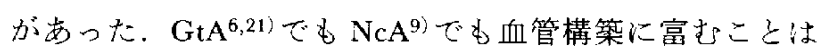
指摘されており，このことは正常下垂体でゴナドトロピン 細胞が血管の豊富な前葉の後内側に特に多(16)ことを考元 ると興味深い. Kovacs ら 9 は は NCA の電顕上の特徵として,

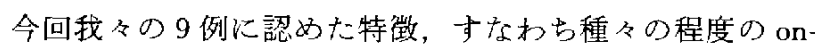
cocytic change, 発育の悪い粗面小胞体抢上び Golgi 装置, そして円形で小型の分泌顆粒の存在を挙げている。また一 方，GtAの電顕所見の報告で, Horvath $5^{6)} 30$ 例の検索 の結果，男性例では NcA 上同梯の所見走示すのが多く， 女性例拉よび一部の男性例ではより分化した形態を認める としている。
以上, GtA と NcA とは臨床上，そして形態的にも往々 にして類似していることは明らかであり，両者を明確に区 別するのは免疫染色によって示されるホルモンの有無のみ と言えるかもしれない，また一力では，Mashiter ら ${ }^{12}$ が 9 例の NcAを培養し, $5 ち 8$ 例に, Asa ら NcA と 5 例の oncocytoma を培養し，その全例にゴナドト ロピンの分泌を認めたと報告している。このことは, NcA は免疫染色では検出できないが潜在的にはゴナドト ロピンを産生する能力を有することを示㖫して沶り，Asa ら゙はNCAの細胞がゴナドトロピン産生細胞に分化しう る，あるい性両者が共通の precursor 有する可能性を指

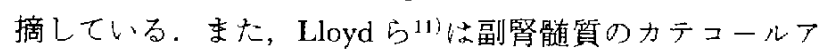
ミンの分泌顆粒の可溶性蛋白の主成分であり，多くの内分 泌細胞汇認められる chromogranin ${ }^{15}$ 亿対する抗体で下垂 体を免疫組織化学的に検索し，正常では糖蛋白ホルモン ( LH, FSH, TSH) 細胞が, 腫瘍では TSH and/or FSH . LH 産生腫瘍㤁よび NcAが陽性を示すことを報告してい る. 我々の症例では GtA の全例と NcAの3 例中 1 例が陽 性を示した. Chromogranin 者 GtAの上り鋭敏なマーカー 上考点ると，この結果も NcAのなかにホれン免疫染色 にて検出されないGtAが含ま机ている可能性を示唼して いる. 果して NcAにGtA と細胞起源を同じくするものが あるのか，あるいはすったく別個に，たと兄ば正常下垂体 汇も存在するといら null cell ${ }^{9 j}$ なと汇起源を求めるべきむ のであるのかは，今後解明を待つ課題である。

\section{$\mathrm{V}$ 結 語}

1. 非機能性下垂体腺腫と分頪されているもののなか に,かなりのゴナドトロピン産生腺腫が含まれている可能 性がある。

2. ゴナドトロピン産生腺腫と null cell adenoma とは免 疫組織化学的に区別できるが, 光顕上, 電影上は概して共 通した所見を示した。

電顕的㛟索においてて御協力頂きさした北里大学電顕センター技 術員の皆様に感謝致します。

\section{文献}

1) Asa SL, Gerrie BM, Singer W, Horvath E, Kovacs K, Smyth HS: Gonadotropin secretion in vitro by human pituitary null cell adenomas and oncocytomas. $J$ Clin Endocrinol Metab 62: 10111019,1986

2) Beckers A, Stevenaert A, Mashiter K, Hennen G: Folliclestimulating hormone-secreting pituitary adenomas. J Clin Endocrinol Metab 61: 525-528, 1985

3) Borges JLG, Ridgway EC, Kovacs K, Rogol AD, Thorner 
MO: Follicle-stimulating hormone-secreting pituitary tumor with concomitant elevation of serum $\alpha$-subunit levels. $J$ Clin Endocrinol Metab 58: 937-941, 1984

4) Cravioto H, Fukaya T, Zimmerman EA, Kleinberg DL, Flamm ES: Immunohistochemical and electron-microscopic studies of functional and non-functional pituitary adenomas including one TSH secreting tumor in a thyrotoxic patient. Acta Neuropathol (Berl) 53: 281-292, 1981

5) Friend JN, Judge DM, Sherman BM, Santen RJ: FSH secreting pituitaty adenomas: Stimulation and suppression studies in two patients. $J$ Clin Endocrinol Metab 43: 650-657, 1976

6) Horvath E, Kovacs K: Gonadotroph adenomas of the human pituitary: Sex-related fine-structural dichotomy. Am J Pathol 117 : 429-440, 1984

7) Hsu SM, Raine L, Fanger H: Use of avidin-biotin-peroxidase complex $(\mathrm{ABC})$ in immunoperoxidase techniques. $J$ Histochem Cytochem 29: 577-580, 1981

8) Kovacs K: Light and electron microscopic pathology of pituitary tumors: Immunohistochemistry, in Black PM (ed): Secretory Tumors of the Pituitary Gland. New York, Raven, 1984, pp 365-375

9) Kovacs K, Horvath E, Ryan N, Erzin C: Null cell adenoma of the human pituitary. Virchows Arch [Pathol Anat] 387: 165-174, 1980

10) Landolt AM, Oswald VM: Histology and ultrastructure of an oncocytic adenoma of the human pituitary. Cancer 31: 1099-1105, 1973

11) Lloyd RV, Wilson BS, Kovacs K, Ryan N: Immunohistochemical localization of chromogranin in human hypophyses and pituitary adenomas. Arch Pathol Lab Med 109: 515-517, 1985

12) Mashiter K, Adams E, Van Noorden S: Secretion of LH, FSH and PRL shown by cell culture and immunocytochemistry of human functionless pituitary adenomas. Clin Endocrinol (Oxf) 15: $103-112,1981$
13) Miura M, Matsukado Y, Kodama T, Mihara Y: Clinical and histopathological characteristics of gonadotropin-producing pituitary adenomas. $J$ Neurosurg 62 : 376-382, 1985

14) Mukai K: Pituitary adenomas. Immunocytochemical study of 150 tumors with clinicopathological correlation. Cancer 52: 648653,1983

15) O'Conner DT, Burton D, Deftos LJ: Immunoreactive human Chromogranin A in diverse polypeptide hormone producing human tumors and normal endocrine tissues. $J$ Clin Endocrinol Metab 57: 1084-1086, 1983

16) Phifer RF, Midgley AR, Spicer SS: Immunohistologic and histologic evidence that follicle-stimulating hormone and luteinizing hormone are present in the same cell type in the human pars distalis. $J$ Clin Endocrinal Metab 36: 125-141, 1973

17) Snyder PJ, Bashey HM, Phillips JL, Gennarelli TA: Comparison of hormonal secretory behavior of gonadotroph cell adenomas in vivo and cultures. $J$ Clin Endocrinol Metab 61: 10611065,1985

18) Snyder PJ, Sterling FH: Hypersecretion of LH and FSH by a pituitary adenoma. J Clin Endocrinol Metab 42: 544-550, 1976

19）武内重二, 青木道夫, 宗光博文, 山上達人, 半田 肇：コ ナドトロピン産生下垂体腺腫。第 3 回下垂体腫瘍 Workshop 講演集. 1983, pp 99-104

20) Trouillas J, Girod C, Sassolas G, Claustrat B, Lheritier M, Dubois MP, Goutelle A: Human pituitary gonadotroph adenoma: Histological, immunocytochemical, and ultrastructural and hormonal studies in eight cases. J Pathol 135: 315-336, 1981

21）土田博美，佐藤修，伝法公䗪，室谷光三：Gonadotropin 産生腺腫の5 例一免疫組織学的. 電顕的険討一。第 3 回下垂 体腫湯 Workshop 講演集. 1983, pp 83-98

〔別刷請求先：干254 神奈川県平塚市南原 1-19 1，平塚市民病院 脳神経外科, 宮崎宏道] 